JOURNAL OF
NATURAL RESOURCES
AND DEVELOPMENT

Research article

\title{
Analysis of the soil and microclimate relationship in two dolines of Carso Huasteco, Mexico
}

Joab R. Quintero-Ruiz a , Laura Yáñez-Espinosa *b, Joel Flores c , Javier Fortanelli ${ }^{b}$, Arturo De-Nova ${ }^{\text {b }}$, Humberto Reyes-Hernandez ${ }^{d}$, Juan P. Rodas-Ortíz ${ }^{c}$

a Programas Multidisciplinarios de Posgrado en Ciencias Ambientales, Universidad Autónoma de San Luis Potosí. Ave. Manuel Nava 201, $2^{\text {nd }}$ Piso, Zona Universitaria, San Luis Potosí, SLP, 78210, México.

b Instituto de Investigación de Zonas Desérticas, Universidad Autónoma de San Luis Potosí. Altair 200, Colonia del Llano, San Luis Potosí, SLP, 78377. México.

División de Ciencias Ambientales, Instituto Potosino de Investigación Científica y Tecnológica A.C. Camino a la Presa San José 2055, Lomas $4^{\text {ta }}$ sección, San Luis Potosí, SLP, 78216, México.

d Facultad de Ciencias Sociales y Humanidades, Universidad Autónoma de San Luis Potosí. Ave. Industrias 101-A, Talleres, San Luis Potosí, SLP, 78399, México.

Corresponding author: lyaneze@uaslp.mx

\section{Article history}

Received 28/12/2018

Accepted 07/05/2019

Published 28/05/2019

\section{Keywords}

Biogeochemistry

Gradient

Karst

Macronutrients

\section{Abstract}

Dolines are karst depressions whose environmental and climatic characteristics in tropical regions are not well known. By measuring and analyzing different components of the microclimate in two dolines located in Tamasopo, Mexico, we aim to contribute to the understanding of the climatic conditions in these formations. The variables analyzed include temperature, solar radiation, soil and air humidity, as well as their relationship to physical and chemical characteristics of the soil such as $\mathrm{pH}$, conductivity, texture, and the content of organic matter, carbon, nitrogen, phosphorus, calcium, potassium, sodium and magnesium. Measurements and soil samples were taken in three strata: bottom, slope and exterior. The results show a gradient in the climatic variables along the three strata, as well as higher concentrations of all elements, except phosphorus, in soil from the dolines, with respect to the exterior. Furthermore, statistical analysis shows a high correlation between the environmental conditions and edaphic properties. The microclimatic factors of the dolines generate a different environment, rich in humidity and with temperatures commonly lower than those present in tropical regions. These conditions cause abrupt changes in the physical and chemical composition of the soil, which present high concentrations of nutrients.

(C) 2019 This is an open access article under the CC BY-NC-ND license (http://creativecommons.org/licenses/bync-nd/4.0/). 


\section{Introduction}

Dolines are closed depressions produced in karst relieves by dissolution processes whose opening and depth dimensions can be very diverse (Waltham et al., 2005). These formations have been used for touristic and recreational purposes; they have also been used in agriculture (especially in those formations with a low depth and a not so steep slope), as illegal dumps and as land banks (CernatičGregorič \& Zega, 2010; Suarez et al., 2010).

Research done in temperate zones have reported the presence of microclimates within these formations, derived from restricted solar radiation, which generate lower temperatures and higher humidity (Bátori, 2009; Bátori, 2012; Raschmanová et al., 2015). This kind of research is scarce in tropical regions, but one study in Brazil (Lobo, 2013) has found similar microclimate traits within dolines. The microclimate influence the vegetation growth and could function as shelter due the climate change (Bátori, 2009; Bátori, 2012; Bátori, 2014a; Bátori, 2014b).

Moreover, the climate has a direct impact on the soil's formation and characteristics; for example, temperature is involved in rock weathering, which increases the presence of minerals. It also impacts on the content of organic matter, since having a high temperature facilitates the decomposition process (Karmakar, 2016). Precipitation releases soluble material from minerals into soil solution, allows the development of microorganisms, facilitates the incorporation of mineral elements from the atmosphere in the form of dissolved ions into the ecosystems and it can leach soluble nutrients (Andrade, 1995).

Considering that the microclimate inside the dolines is different from the environment of the exterior, its influence is expected to cause soil changes. In this way, an analysis of the variations of the microclimate and their correlation with changes in soil features would allow a better understanding of why a typical vegetation establishes itself in these formations. Consequently, the aim of this study is to contribute knowledge about the environmental characteristics of dolines and their impact on soil composition. In order to do so, a hypothesis was established stating that, in dolines, the restriction of radiation generates a decrease in temperature and an increase in environment humidity, and that this is correlated with a greater number of nutrients and organic matter.

\section{Methods}

\subsection{Study site}

Two dolines located in the city of Tamasopo, San Luis Potosí, Mexico (Figure 1) were selected. Tamasopo is part of the Carso Huasteco, a region in the Sierra Madre Oriental composed of limestones from the Upper Cretaceous (Morrone, 2005).

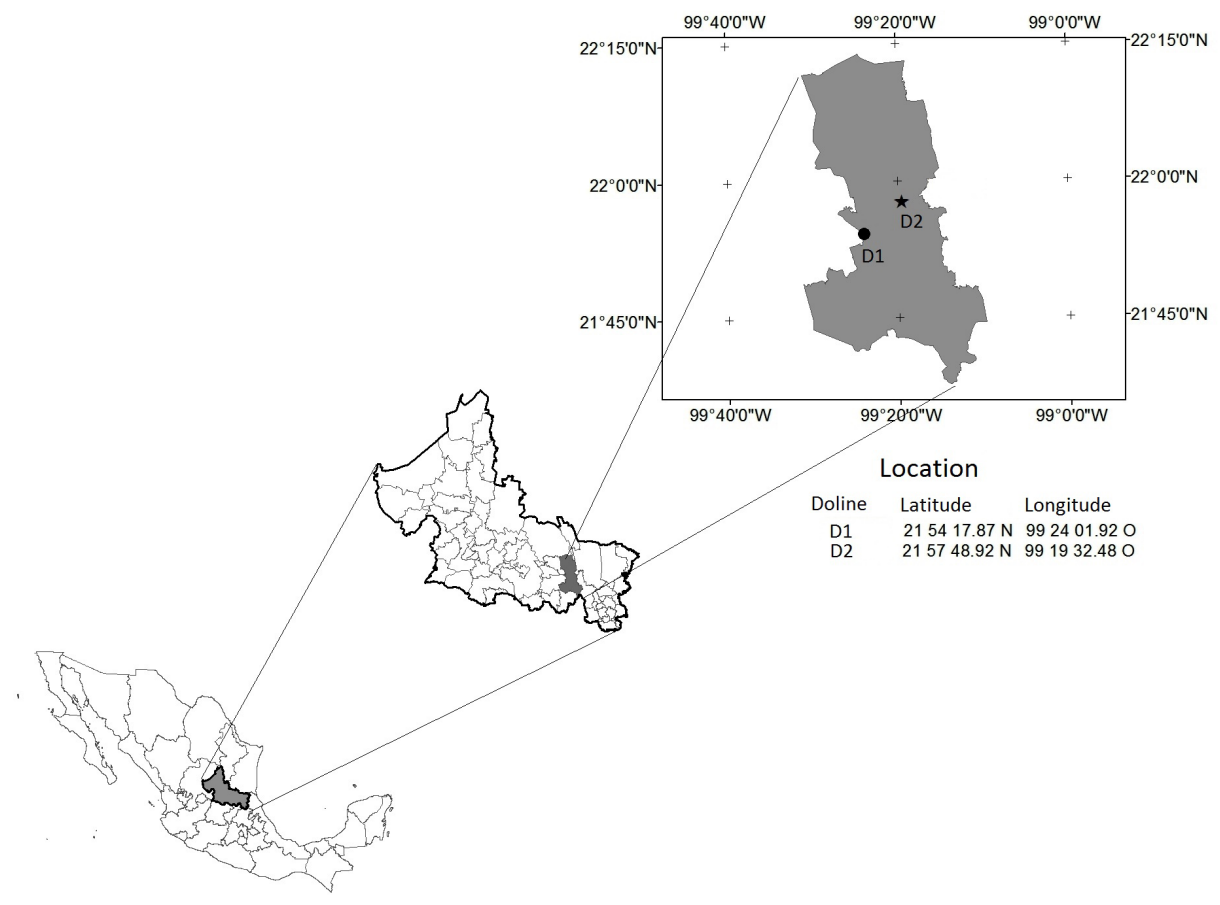

Figure 1: Location of the study sites 
In each doline there were three differences in the geoform components (GC): the bottom, the slope and the exterior. Specific characteristics were found in the $\mathrm{GC}^{\prime}$ s of each doline. Regarding doline 1 (D1) (Figure 2), its bottom has rocks, most of which have large dimensions, a slight slope and a small area next to the southeast end wall where only rupiculous flora live. On the contrary, the bottom of doline 2 (D2) (Figure 3 ) is totally flat, but it also has some large chunks of rock.

In D1, the slope faces southeast - northeast, has a gradient of between $50^{\circ}$ and $65^{\circ}$ near the edge, and has arboreal vegetation. Further down, it turns rocky, with scarce soil and a predominantly herbaceous vegetation. D2 has a peripheral shaped slope which surrounds the bottom completely (Figure 3); this slope, alike D1, has areas with many small rocks with some vegetation, as well as areas where there is a greater soil retention and arboreal vegetation. Past the slope, there is a wall surrounding the circumference of the doline.

Tamasopo is relevant by sugar cane plantations with a surface of approximately $5.8 \mathrm{~km}^{2}$, which were introduced into the region by the
Spanish settlers (Aguilar, 2010). There is a sugar refining mill which process the sugar cane harvests of the region with a production of about $35.9 \mathrm{t} \mathrm{ha}^{-1}$ year ${ }^{-1}$ (Aguilar, 2010). Most of the population is dedicated to the cultivation of sugar cane and, to a lesser extent, to plantations of corn, beans and citrus. Almost $500 \mathrm{~m}$ from D2, there are sugar cane plantations cultivated with pesticides and fertilizers rich in phosphorous as well as irrigation system. Near D1 there are rainfed cornfields traditionally cultivated but use the same pesticides and fertilizers rich in phosphorous also used for sugar cane plantations.

The exterior of both formations is also quite different. Regarding D1, Mexico's National Statistics, Geography and Informatics Institute (Instituto Nacional de Geografía Estadística e Informática, 2001a), the vegetation of the region corresponds a tropical rainforest; however, the surrounding vegetation corresponds to a tropical deciduous forest with disturbance signs. According to INEGI (Instituto Nacional de Geografía Estadística e Informática, 2001a), D2 has the type of vegetation that corresponds to a tropical deciduous forest. D1 has a temperate, semi-humid climate with summer rainfall $(A) C(w 1)$,
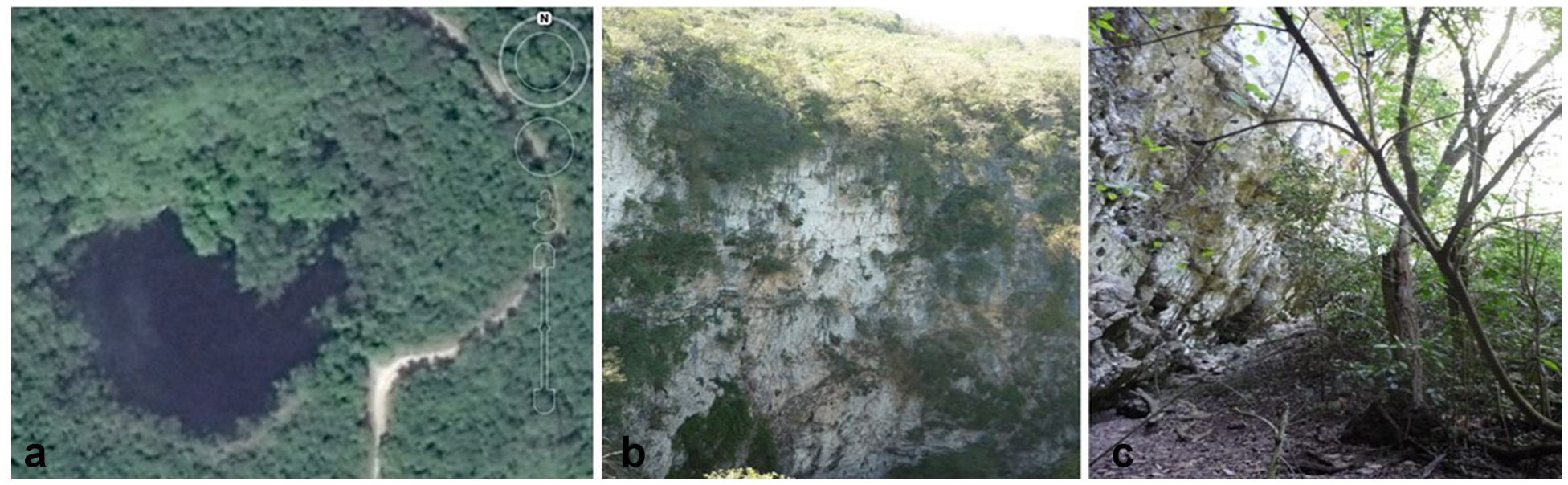

Figure 2: Doline D1 a) view from the top, b) southwest wall, c) bottom of dolinesites
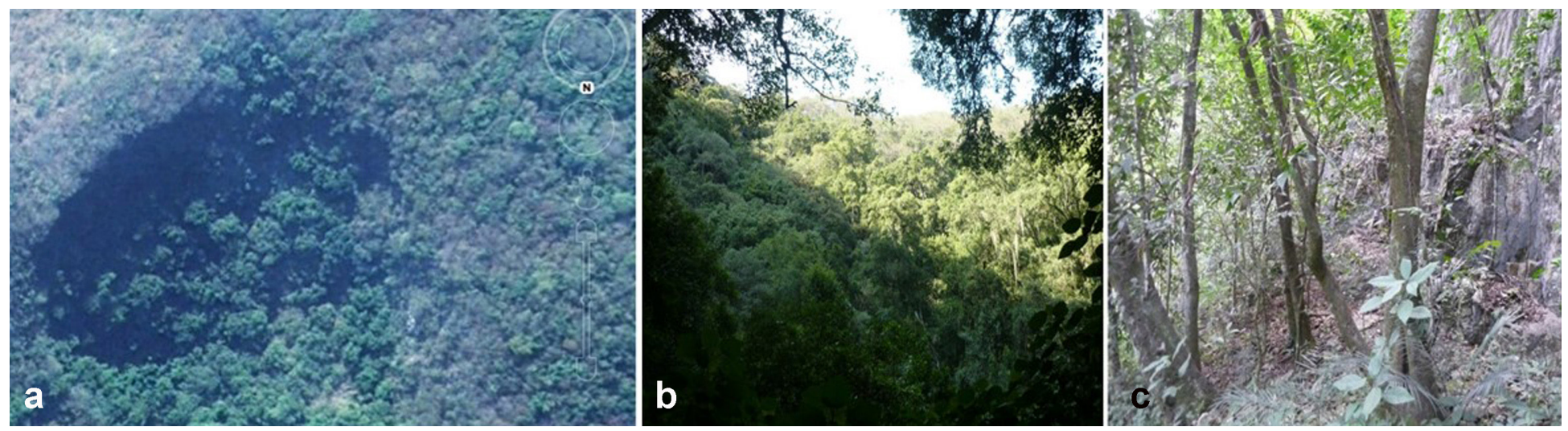

Figure 3: Doline D2 a) view from the top, b) view from the bottom, c) beginning of the slopesites 
whereas D2 has a semi-humid warm climate, with abundant summer rainfall $(\mathrm{A}) \mathrm{Ca}(\mathrm{m})(\mathrm{w})$ (Instituto Nacional de Geografía Estadística e Informática, 2001b).

\subsection{Soil Analysis}

From each GC of both dolines, five sub-samples were extracted at a \pm $30 \mathrm{~cm}$ depth since the soil was in a lithic phase; the sub-samples were mixed in order to obtain a sample for each GC.

The samples were taken to the laboratory of the Desert Area Research Institute of the Autonomous University of San Luis Potosí, where they were dried and later sifted in order to run the following tests:

Soil texture. The test was run following Bouyoucos's method. The results obtained were classified in accordance with the quality evaluation and soil health guidelines of USDA (Li, 2015). pH Test. 10 $\mathrm{g}$ of soil, which had been previously sifted using a $2 \mathrm{~mm}$ screen and mixed with $20 \mathrm{ml}$ of deionized water for 30 minutes and measured with a potentionmeter, were chosen (Corning, 450). Electrical Conductivity. Using a dry sample with deionized water, a $300 \mathrm{~g}$ saturated paste was made. The paste was filtered using Whatman filter paper Grade 42 for 3 hours until a clear extract was obtained, which was measured using a conductivity meter (Corning, Check-Mate 90).

The following tests were carried out at the Institute for Technological and Scientific Research (IPICYT) of San Luis Potosí, Mexico: Organic matter, through the Calcination Test (NOM-021-RECNAT-2000, 2000), Total Organic Carbon and Total Nitrogen, an elementary combustion analyzer (Costech, California, Modelo 1016) was used. Extractable phosphorous, via an $862 \mathrm{~nm}$ spectrophotometer (UV-Vis Thermo Sci, Genesys 10 uv), using the Bray-Kurtz solution extract technique.

Lastly, interchangeable calcium (Ca), potassium ( $\mathrm{K}$ ), sodium ( $\mathrm{Na}$ ) and magnesium $(\mathrm{Mg}$ ) bases were measured using the Inductively Coupled Plasma technique, also known as ICP, using an ICP-OES analizer (Varian 730-Es).

\subsection{Climatic Factors}

The irradiance $\left(\mathrm{Wm}^{-2}\right)$ from the bottom, the slope and the exterior of both dolines ( $n=300$ per doline) was analyzed; in each one of the four seasons, a quantum sensor (Quantum MQ-200, Apogee) was used. The data were registered approximately within a 30-minute period; this was the estimated time taken to reach the bottom of the dolines. Similarly, the relative humidity of the soil was measured ( $n=300$ per doline) using a $\mathrm{pH}$ and humidity meter (Kelway HB2, Kel Instruments) at a 15 to $20 \mathrm{~cm}$ depth. To analyze the temperature $(\mathrm{n}=$ 6426 per doline) and humidity of the air ( $n=6426$ per doline), HOBO (pro v2, Onset) digital sensors were used, which registered data every four hours, from July 2014 to June 2015. These sensors were placed at the bottom, the slope and the exterior of the dolines.

\subsection{Statistical Analysis}

The air and soil relative humidity data were square-root transformed to carry out the statistical analyses. A multi-factorial analysis of variance (ANOVA) with random-effects was conducted to identify the differences of the climatic factors, in the GC for each doline and seasons. A multiple comparisons Duncan's test ( $p<0.05)$ was applied. The total data for each factor per doline were $n=300$. In the case of temperature and humidity of the air, the daily average of the period obtained was the one in which the irradiance and the humidity of the soil were registered; thus, a sample of 100 data was obtained for each one of the factors. The statistical analyses were conducted with the program XLSTAT (XLSTAT, 2015).

\section{Results}

\subsection{Soil Analysis}

The soil analysis showed that the bottom of D1 is composed of an argillaceous, arenaceous loam, whereas the bottom of D1 is argillaceous. The texture of the slope of both dolines is arenaceous loam. The soil of the exterior of D1 is argillaceous while D2's is an argillaceous, arenaceous loam. Regarding the $\mathrm{pH}$, the samples in D1 were slightly acidic at the bottom, whereas the $\mathrm{pH}$ of the slope and the exterior were alkaline. In $\mathrm{D} 2$, the $\mathrm{pH}$ was alkaline in the three strata, being the highest value at the bottom, followed by the slope, whereas the lowest value was registered by the exterior (Table 1).

The conductivity test revealed a notable difference between the sites of D1, which presented a gradient from the exterior to the bottom, with an exponential increase; whereas bottom of D2 presented had the lowest values, being the slope where the highest conductivity was found (Table 1).

Regarding the organic matter, only one gradient was observed in D1, with the bottom having the highest concentration, whereas in D2, the slope was the site with the highest concentration, and the bottom and the exterior presented a very similar concentration (Table 1). The $\mathrm{C}$ and $\mathrm{N}$ concentration presented no gradient. Both elements presented a higher concentration in the slope, in both dolines. D1 presented the lowest concentration in the exterior, whereas in D2, the bottom did (Table 1). The analysis of $\mathrm{P}$ showed a gradient only in D2, whose bottom presented a higher concentration, whereas the exterior of D1 presented the highest concentration and its slope the lowest one (Table 1). Regarding the interchangeable bases, in each one of the elements of D1 a gradient was observed, which increased from the exterior to the bottom. In D2, no gradient was observed; however, each one of the elements, except $\mathrm{Na}$, presented a higher concentration in the slope (Table 1).

\subsection{Climatic Factors}

The humidity of the soil of D1 and D2 was statistically different among the three GC's (D1: $F=79.924, d f=2, p<0.0001$; D2: $F=196.947$, $d f=$ $2, p<0.0001)$. A larger percentage of humidity was observed in the bottom of both dolines, whereas the slope had presented a smaller percentage (Table 2). There were also seasonal differences (D1: $F=$ 16.087, $d f=3, p<0.0001 ; D 2: F=121.908, d f=3, p<0.0001)$, with 
Table 1: Soil variables per GC of two dolines in Tamasopo, San Luis Potosi, Mexico.

\begin{tabular}{|c|c|c|c|c|c|c|c|c|c|c|}
\hline Strata & $\mathrm{pH}$ & $\mathrm{S}$ & $\mathrm{M} . \mathrm{O}$ & $\mathrm{C}$ & $\mathrm{N}$ & $\mathrm{P}$ & $\mathrm{Ca}$ & $\mathrm{K}$ & $\mathrm{Na}$ & $\mathrm{Mg}$ \\
\hline $\mathrm{D} 1$ & & $\mu \mathrm{S}$ & $\%$ & $\%$ & $\%$ & $\mathrm{mg} / \mathrm{Kg}$ & $\mathrm{mg} / \mathrm{Kg}$ & $\mathrm{mg} / \mathrm{Kg}$ & $\mathrm{mg} / \mathrm{Kg}$ & $\mathrm{mg} / \mathrm{Kg}$ \\
\hline B & 6.62 & 23350 & 7.88 & 4.79 & 0.68 & 17.25 & 4624.21 & 4740.01 & 77.01 & 847.81 \\
\hline S & 7.16 & 408 & 4.61 & 6.41 & 0.73 & 0.77 & 4570.78 & 297.89 & 11.07 & 577.98 \\
\hline Ex & 7.65 & 237 & 4.27 & 4.00 & 0.56 & 39.06 & 3209.63 & 98.97 & 10.36 & 60.85 \\
\hline D2 & & & & & & & & & \\
\hline B & 7.31 & 294 & 7.35 & 4.33 & 0.63 & 21.18 & 3719.66 & 393.19 & 11.38 & 843.58 \\
\hline S & 7.25 & 638 & 12.44 & 7.67 & 0.90 & 6.35 & 5115.73 & 463.62 & 11.16 & 961.50 \\
\hline Ex & 7.13 & 434 & 7.47 & 5.85 & 0.78 & 0.96 & 4111.27 & 343.53 & 5.30 & 874.91 \\
\hline
\end{tabular}

$\mathrm{B}=$ bottom; $\mathrm{S}=$ slope; $\mathrm{Ex}=$ exterior

winter having the highest humidy and summer having the lowest one (Table 3). In the seasonal analysis, this was observed in both dolines: $(D 1: F=22.247, d f=11, p<0.0001 ; F=82.900, d f=11, p<0.0001)$, being the bottom the place with the highest humidity during the year, even having a percentage higher than $90 \%$ in all the seasons of D1 and $100 \%$ during winter in D2, whereas the lowest values were had in almost all the seasons in both slopes (Table 4).

Regarding the irradiance, the bottom was the stratum with the lowest amount of solar radiation in both dolines, whereas the exterior was the one with the highest concentration. In D1, the exterior and the slope were similar but at the same different $(F=34.418, d f=2, p<$ 0.0001), whereas in D2 $(F=11.020, d f=2, p<0.0001)$, the bottom and the slope were similar and at the same time different from the exterior (Table 2). The analysis per season showed, in both dolines (D1: $F=13.967, d f=3, p<0.0001 ; D 2: F=2.855, d f=3, p<0.0374$ ), that summer is the season with the highest solar radiation, followed by spring, winter and autumn (Table 3 ).

The analysis of GC per season showed that in $\mathrm{D} 1(\mathrm{~F}=12.331, \mathrm{df}=11$, $p<0.0001$ ) the slope in spring and summer is exposed to the highest solar radiation because its Southern exposition, and the bottom presented the lowest radiation, because of the shady projection from the vertical wall during autumn and winter (Table 4). In D2 ( $F=3.107$, $\mathrm{df}=11, \mathrm{p}<0.0006)$, the exterior presented the highest radiation during the summer, whereas the lowest radiation was registered at the bottom during autumn. Throughout the year, the bottom presented the lowest radiation values of the three GC's (Table 4).

The analysis of relative humidity in the air showed that there are differences among the three places in both dolines (D1: $F=304.293$, $d f=2, p<0.0001 ; D 2: F=316.106, d f=2, p<0.0001$ ). In both formations, a clear gradient was observed. In the bottoms, a higher percentage of humidity appeared. That percentage gradually decreases down to the exterior (Table 2). Similarly, the seasonal analysis revealed that in both dolines (D1: $F=56.161, d f=3, p<0.0001 ; D 2: F=164.130, d f=3$, $p<0.0001$ ) autumn had the highest percentage of humidity, followed by winter, summer and spring (Table 3 ).

The seasonal analysis per GC showed a tendency in both dolines (D1: $F=71.927, d f=11, p<0.0001 ; D 2: F=110.606, d f=11, p<0.0001)$, with the bottom, showing air humidity higher than $90 \%$ all year round and higher than $99 \%$ in the winter. However, during the summer there was a difference of almost $3 \%$ between both dolines attributed to a larger diameter in D2 because it allows airflows and a higher release of humidity (Table 4). Likewise, the exterior of both dolines showed lower values of air humidity, and the lowest during the spring.

The analysis of temperature showed that there is a difference among the three strata $(F=341.055, d f=2, p<0.0001)$ in $D 1$, whereas in D2, the exterior and the slope were similar but at the same time different from the bottom $(F=200.270, d f=2, p<0.0001)$. In both dolines, there is a gradient inversely related to humidity, where the bottom presented the lowest temperature, with a $2.2{ }^{\circ} \mathrm{C}$ in comparison to the exterior in D1 and $1.6{ }^{\circ} \mathrm{C}$ in D2 (Table 2). These differences result relevant considering that for each $100 \mathrm{~m}$ of elevation there is a decrease of $0.48{ }^{\circ} \mathrm{C}$ to $1{ }^{\circ} \mathrm{C}$ in the temperature (NOM-021RECNAT-2000, 2000; XLSTAT, 2015). The analysis showed differences among all the seasons in both dolines (D1: $F=2456.008, d f=3, p$ 0.0001; D2: $F=2841.209$, $d f=3, p<0.0001)$.

The seasonal analysis per GC during the summer in both dolines (D1: $F=741.786, d f=11, p<0.0001 ; D 2: F=816.664, d f=11, p<0.0001$ ) showed that the exterior and the slope presented the warmest temperatures; whereas the coldest temperatures were registered in the three GC's during the winter, mainly in the bottom (Table 4). 
Table 2: ANOVA of the climatic variables per CG of two dolines in Tamasopo, San Luis Potosi, Mexico.

\begin{tabular}{|c|c|c|c|c|}
\hline Strata & Temperature & Air humidity & Soil humidity & Irradiance \\
\hline D1 & & & & \\
\hline B & $18.13 \pm 0.08 \mathrm{c}$ & $98.16 \pm 0.09 \mathrm{a}$ & $95.25 \pm 0.97 \mathrm{a}$ & $19.89 \pm 4.07 \mathrm{~b}$ \\
\hline S & $20.15 \pm 0.10 \mathrm{~b}$ & $92.68 \pm 0.23 \mathrm{~b}$ & $63.87 \pm 2.53 \mathrm{c}$ & $157.62 \pm 22.15 \mathrm{a}$ \\
\hline Ex & $20.33 \pm 0.10 \mathrm{a}$ & $91.90 \pm 0.23 \mathrm{c}$ & $78.90 \pm 2.07 \mathrm{~b}$ & $170.82 \pm 14.85 \mathrm{a}$ \\
\hline D2 & & & & \\
\hline B & $19.64 \pm 0.09 \mathrm{~b}$ & $97.19 \pm 0.14 \mathrm{a}$ & $93.80 \pm 1.11 \mathrm{a}$ & $97.66 \pm 11.29 \mathrm{~b}$ \\
\hline S & $21.24 \pm 0.10 \mathrm{a}$ & $91.82 \pm 0.23 \mathrm{~b}$ & $52.00 \pm 3.27 \mathrm{c}$ & $116.73 \pm 13.35 \mathrm{~b}$ \\
\hline Ex & $21.31 \pm 0.10 \mathrm{a}$ & $90.28 \pm 0.24 \mathrm{c}$ & $70.25 \pm 2.49 \mathrm{~b}$ & $192.57 \pm 19.70 \mathrm{a}$ \\
\hline
\end{tabular}

$\mathrm{B}=$ bottom; $\mathrm{S}=$ slope; $\mathrm{Ex}=$ exterior. Different letters mean significant differences, $\mathrm{p}<0.05$, Duncan's test. $\pm \mathrm{S}$.E.

Table 3: ANOVA of the climatic variables per seasons of two dolines in Tamasopo, San Luis Potosi, Mexico.

\begin{tabular}{|c|c|c|c|c|c|c|c|c|}
\hline Season & \multicolumn{2}{|c|}{ Temperature } & \multicolumn{2}{c|}{ Air humidity } & \multicolumn{2}{c|}{ Soil humidity } & Irradiance \\
\hline & D1 & D2 & D1 & D2 & D1 & D2 & D1 & D2 \\
\hline Spr & $21.74 \pm 0.08 \mathrm{~b}$ & $23.48 \pm 0.08 \mathrm{~b}$ & $92.64 \pm 0.25 \mathrm{c}$ & $90.129 \pm 0.29 \mathrm{c}$ & $82.26 \pm 2.74 \mathrm{a}$ & $75.86 \pm 2.56 \mathrm{~b}$ & $156.34 \pm 23.28 \mathrm{a}$ & $141.97 \pm 16.04 \mathrm{ab}$ \\
\hline Sum & $23.19 \pm 0.06 \mathrm{a}$ & $24.45 \pm 0.06 \mathrm{a}$ & $92.97 \pm 0.24 \mathrm{c}$ & $90.857 \pm 0.28 \mathrm{~b}$ & $67.29 \pm 2.67 \mathrm{~b}$ & $56.73 \pm 4.14 \mathrm{c}$ & $172.72 \pm 22.47 \mathrm{a}$ & $172.89 \pm 21.35 \mathrm{a}$ \\
\hline Aut & $18.56 \pm 0.09 \mathrm{c}$ & $19.53 \pm 0.09 \mathrm{c}$ & $96.02 \pm 0.19 \mathrm{a}$ & $95.830 \pm 0.17 \mathrm{a}$ & $82.66 \pm 2.73 \mathrm{a}$ & $58.06 \pm 3.08 \mathrm{c}$ & $37.45 \pm 9.01 \mathrm{c}$ & $102.97 \pm 16.40 \mathrm{~b}$ \\
\hline Wint & $14.65 \pm 0.08 \mathrm{~d}$ & $15.46 \pm 0.07 \mathrm{~d}$ & $95.37 \pm 0.24 \mathrm{~b}$ & $95.562 \pm 0.20 \mathrm{a}$ & $85.13 \pm 2.16 \mathrm{a}$ & $97.40 \pm 0.76 \mathrm{a}$ & $97.93 \pm 16.36 \mathrm{~b}$ & $124.78 \pm 17.59 \mathrm{ab}$ \\
\hline
\end{tabular}

Spr: spring; Sum: summer; Aut: autumn; Wint: winter. Different letters mean significant differences, $p<0.05$, Duncan's test. \pm S.E.

Table 4: ANOVA of the environmental factors of two dolines in Tamasopo, San Luis Potosi, Mexico.

\begin{tabular}{|c|c|c|c|c|c|c|c|c|c|}
\hline \multicolumn{2}{|c|}{ Season } & \multicolumn{2}{|c|}{ Temperature } & \multicolumn{2}{|c|}{ Air humidity } & \multicolumn{2}{|c|}{ Soil humidity } & \multicolumn{2}{|c|}{ Irradiance } \\
\hline & & D1 & D2 & D1 & D2 & D1 & D2 & D1 & D2 \\
\hline \multirow[t]{3}{*}{ Spr } & B & $19.38 \pm 2.23 d$ & $21.77 \pm 2.48 \mathrm{e}$ & $96.76 \pm 0.20 b$ & $96.88 \pm 0.26 b$ & $97.60 \pm 1.22 a b$ & $93.600 \pm 1.65 a b$ & $30.04 \pm 11.79 b c$ & $113.39 \pm 21.67 \mathrm{bcd}$ \\
\hline & $S$ & $22.82 \pm 0.14 b$ & $24.29 \pm 0.14 c$ & $91.18 \pm 0.49 \mathrm{e}$ & $87.68 \pm 0.53 \mathrm{~g}$ & $62.00 \pm 5.55$ def & $53.400 \pm 3.48 d$ & $246.61 \pm 51.44 a$ & $145.86 \pm 28.5 \mathrm{abcd}$ \\
\hline & Ex & $23.03 \pm 0.13 b$ & $24.39 \pm 0.14 b c$ & $89.97 \pm 0.49 f$ & $85.83 \pm 0.56 h$ & $87.20 \pm 3.11 b c$ & $80.600 \pm 3.31 c$ & $192.37 \pm 34.21 \mathrm{a}$ & $166.64 \pm 32.27 \mathrm{abc}$ \\
\hline \multirow[t]{3}{*}{ Sum } & B & $22.17 \pm 0.06 c$ & $23.80 \pm 0.11 d$ & $97.37 \pm 0.19 b$ & $93.80 \pm 0.44$ de & $91.60 \pm 2.41 \mathrm{abc}$ & $95.200 \pm 2.21 \mathrm{ab}$ & $37.49 \pm 9.57 b c$ & $123.59 \pm 30.76 \mathrm{bcd}$ \\
\hline & $S$ & $23.55 \pm 0.12 \mathrm{a}$ & $24.75 \pm 0.11 a b$ & $91.49 \pm 0.49$ e & $90.06 \pm 0.50 \mathrm{f}$ & $57.08 \pm 3.85$ ef & $23.400 \pm 4.90 \mathrm{f}$ & $274.08 \pm 48.96 a$ & $157.03 \pm 30.8 \mathrm{abcd}$ \\
\hline & Ex & $23.84 \pm 0.11 a$ & $24.81 \pm 0.12 \mathrm{a}$ & $90.05 \pm 0.47 f$ & $88.71 \pm 0.52 \mathrm{~g}$ & $53.20 \pm 2.92 f$ & $51.600 \pm 4.58 \mathrm{~d}$ & $206.60 \pm 30.70 a$ & $238.06 \pm 45.09 a$ \\
\hline \multirow[t]{3}{*}{ Aut } & B & $17.54 \pm 0.14 \mathrm{e}$ & $18.78 \pm 0.16 \mathrm{~g}$ & $99.26 \pm 0.14 \mathrm{a}$ & $98.53 \pm 0.18 a$ & $92.20 \pm 2.50 \mathrm{abc}$ & $86.400 \pm 2.99 b c$ & $1.17 \pm 0.16 c$ & $66.74 \pm 18.46 \mathrm{~d}$ \\
\hline & $S$ & $19.03 \pm 0.17 \mathrm{~d}$ & $19.88 \pm 0.16 f$ & $94.52 \pm 0.40 c$ & $95.24 \pm 0.32 c$ & $65.40 \pm 5.99 \mathrm{de}$ & $34.000 \pm 2.52 \mathrm{e}$ & $15.59 \pm 3.70 \mathrm{bc}$ & $84.72 \pm 24.63 \mathrm{~cd}$ \\
\hline & Ex & $19.11 \pm 0.16 \mathrm{~d}$ & $19.935 \pm 0.16 f$ & $94.26 \pm 0.39 \mathrm{~cd}$ & $93.72 \pm 0.35$ de & $90.400 \pm 2.89 a b c$ & $53.800 \pm 3.35 d$ & $95.59 \pm 22.85 b$ & $157.45 \pm 36.76 \mathrm{abcd}$ \\
\hline \multirow[t]{3}{*}{ Wint } & B & $13.40 \pm 0.08 \mathrm{~g}$ & $14.22 \pm 0.09 \mathrm{i}$ & $99.23 \pm 0.14 \mathrm{a}$ & $99.54 \pm 0.10 \mathrm{a}$ & $99.60 \pm 0.28 a$ & $100 \pm 0 \mathrm{a}$ & $10.87 \pm 2.75 b c$ & $86.90 \pm 16.20 \mathrm{~cd}$ \\
\hline & $S$ & $15.18 \pm 0.17 f$ & $16.05 \pm 0.14 \mathrm{~h}$ & $93.55 \pm 0.49 \mathrm{~cd}$ & $94.29 \pm 0.39 \mathrm{~cd}$ & $71.00 \pm 4.42 \mathrm{~d}$ & $97.200 \pm 1.19 a$ & $94.20 \pm 33.65 b$ & $79.30 \pm 19.17 \mathrm{~cd}$ \\
\hline & Ex & $15.36 \pm 0.15 f$ & $16.12 \pm 0.14 \mathrm{~h}$ & $93.32 \pm 0.47 d$ & $92.85 \pm 0.42 \mathrm{e}$ & $84.80 \pm 2.61 c$ & $95.000 \pm 1.87 \mathrm{ab}$ & $188.70 \pm 26.06 \mathrm{a}$ & $208.13 \pm 42.42 \mathrm{ab}$ \\
\hline
\end{tabular}

Spr: spring, Sum: summer, Aut: autumn, Wint: winter. $B=$ bottom, $S=$ slope, Ex $=$ exterior. Different letters mean significant differences, $p<0.05$, Duncan's test. \pm S.E 


\section{Discussion}

The climatic factors analyzed showed significant differences between the GC's, which mark a clear and evident gradient influenced by the geomorphological characteristics present in each doline. Temperature is influenced by the amount of radiation that each formation receives, decreasing abruptly at the bottom, causing the registered temperature to be lower, and presenting an average barely above the isotherm determined as the limit of the intertropical zone $\left(18^{\circ} \mathrm{C}\right)$. However, during the winter, the temperature drops below the isotherm, something atypical for the tropical zones (Vargas, 2002).

The thermal variation registered during the seasons can be ascribed to the latitudinal location. The tropical zones closest to the Ecuador present a low thermal amplitude, which increases with distance. A thermal variation of $8{ }^{\circ} \mathrm{C}$ is present in places that are close to $23^{\circ}$ latitude (González-Medrano, 2012) similar to that registered in both dolines.

Temperature is inversely related to humidity. As temperature drops there is less energy to dissipate humidity as vapor (Çengel, 2007), generating higher concentrations in the air and soil at the bottom. Soil humidity is also influenced by relief in both dolines, where the water drains to the bottom with higher presence of clay, which favors a high-water retention. Regarding air humidity, even when it was 7 $\%$ lower in the exterior in relation to the bottom, it was $12 \%$ lower in relation to a station located $9.8 \mathrm{~km}$ from D2 and $15.9 \mathrm{~km}$ from D1 (Comisión Nacional del Agua, personal communication, Aug 2015).

Limestone weathering is also influenced by temperature. Sudden changes of this factor generate affectations on the surface of the stone, whereas high temperatures, along with humidity, intensify the speed of chemical reactions that alter the stones. The carbonic acid produced as a result of mixing water with $\mathrm{CO}_{2}\left[\mathrm{CO}_{2}+\mathrm{H}_{2} \mathrm{O}=\right.$ $\left.\mathrm{H}_{2} \mathrm{CO}_{3}\right]$ (Duque, 2003), creates calcium bicarbonate $\left[\mathrm{CO}_{3} \mathrm{H}_{2}+\mathrm{CO}_{3} \mathrm{Ca}=\right.$ $\left(\mathrm{CO}_{3} \mathrm{H}\right)_{2} \mathrm{Ca}$ ] when reacts with the limestone, which is solubilized with water (Straulino, 2012).

Carbonic acid, minerals and salts dissolved by weathering and limestone solution reach the interior of the dolines. In D1 a higher concentration of $\mathrm{Ca}, \mathrm{K}, \mathrm{Na}$ and $\mathrm{Mg}$ occurred at the bottom caused by the entrainment of these elements, resulting in an extremely high conductivity compared to the those in the slope and the exterior. Nevertheless, this does not imply an elevated salinity, since it has been stipulated that soil is saline starting at $4 \mathrm{dS} \mathrm{m}^{-1}$, whereas the highest reached value was $2.3 \mathrm{dS} \mathrm{m} \mathrm{m}^{-1}$. The presence of salts, especially $\mathrm{Ca}$ and $\mathrm{Mg}$, would result in soil alkalization, as it happened in D2; however, at the bottom of D1, the soil was slightly In D2 the slope presented the highest conductivity and concentration of $\mathrm{Ca}, \mathrm{K}$ and $\mathrm{Mg}$. This could be due to the shape of the doline, which presents a soft slope around the bottom covered with arboreal vegetation. A greater amount of materials is retained on the slope, so the supply of salts and minerals to the bottom is not constant as in D1. It is worth mentioning that the values of nutrients, in both dolines, are in optimal levels for most of the agronomic and forage crops (Espinoza et al., 2012).
A relationship between $\mathrm{C}$ and $\mathrm{N}$ with the soil humidity gradient was observed; both elements were found in higher concentrations in places with lower humidity, decreasing towards the places with higher humidity. Regarding $C$, this is attributed to the capture of Carbon, which increases with humidity (Campo et al., 2016). In the case of $\mathrm{N}$, its presence is more complex since, on one hand, an increase of $\mathrm{N}$ is visible in places where the soil humidity is lower, which would pose that the lack of humidity prevents it from being leached or to present a denitrification effect (Grageda-Cabrera, 2000). The organic matter releases $\mathrm{N}$ when decomposing, which is why there was a larger amount of $\mathrm{N}$ in places with higher concentrations of $\mathrm{O}$. $\mathrm{M}$. The values of $\mathrm{N}$ obtained turned out to be higher than the ones obtained in other works about tropical rainforests soils (Koyoc-Ramírez et al., 2015; Salazar et al., 2004).

Regarding the O. M., it appeared in D1 as an inverse gradient to temperature, coinciding with observations that note that as temperature increases, O. M. decomposition increases as well (Arguello, 1991). The physical characteristics of each doline are another factor that affects the concentrations of $\mathrm{O}$. M. While the steep slope in D1 favors the dragging of litter and other components of organic matter to the bottom by gravity and precipitation, in D2 the smooth rocky slope covered with vegetation retains them resulting in a higher concentration of $\mathrm{O}$. M. In both dolines, the percentage of organic matter was higher than the one in the exterior, as well as the one reported in other works (Koyoc-Ramírez et al., 2015; Ávila \& Zamora, 2010).

Finally, $\mathrm{P}$ was found in higher concentrations on the exterior of D1 and at the bottom of D2. Regarding D1, the presence of crops in the surroundings was observed, and probably the use of phosphorus oxide $\left(\mathrm{P}_{2} \mathrm{O}_{5}\right)$ commonly used as fertilizer in Tamasopo (Aguilar et al. 2013) could be the reason for its concentration. The values present at the bottom of both dolines were similar and considered as midhigh values of $\mathrm{P}$ (Sainz et al., 2011), whereas the $\mathrm{pH}$ levels of these places (6.6 in D1 and 7.3 in D2) are in a range considered optimal for $P$ availability (Rojas, 2015). The presence of high levels of $P$ in the bottoms is attributed to the soil texture. Soil texture affects $P$ availability, influencing O.M. accumulation and cycling, soil microbial activity and physico-chemical equilibria, which allows a higher retention of water; this generates an increase of phosphate ions in solution (Rojas, 2015). Previous studies have shown that P extracted by the method of Bray and Kurtz have a predominantly inorganic origin (Suñer \& Galantini, 2015). In the case of the slopes, higher sand content causes dilution of the $\mathrm{P}$ content, which decreases the total reserve of $P$ in sandy soils.

\section{Conclusions}

The microclimatic factors of the dolines create a different environment, rich in humidity and with lower temperatures than the ones commonly present in tropical regions. These conditions generate abrupt changes in the physical and chemical composition of the soil. 
There were three factors, which were identified as most influential, in the soil characteristics. First, temperature: which influences humidity, as in biochemical reactions. Low temperature is assumed as low energy, required for various biogeochemical processes, such as $\mathrm{O}$. M. decomposition, which is why these can be slower, mainly during winter.

Secondly, humidity: almost saturated during the whole year, which generates a constant limestone solution, and intervenes in biogeochemical processes like phosphorus availability.

Thirdly, geographic depression: which causes various elements coming from vegetation, and rock to be stocked at the bottom of these formations; therefore, despite constant leaching, these present a high concentration.

Finally, the soil of the dolines present high concentrations of nutrients and essential compounds for plant growth, which is why they could be considered as optimal soils for crops.

\section{Acknowledgments and Financial support}

We thank Rosa Martínez for her support in elaborating the map. The research was financed by Mexico's National Science and Technology Council (CONACYT) through the PhD scholarship awarded to JRQR (370082), the IDEA WILD Foundation, and the Autonomous University of San Luis Potosí through the project: "Composition and structure of vegetation in environmental gradients in dolines of the CarsoHuasteco "(C15-FAI-04-113.113) granted to LYE.

\section{References}

Aguilar, N. (2010). La caña de azúcar y sus derivados en la Huasteca San Luís Potosí, México. Diálogos, Revista Electrónica de Historia, 11(1), 83-110.

Aguilar, N., Olvera, L. A., \& Galindo, G. (2013). Evaluación de aptitud de tierras al cultivo de caña de azúcar en la Huasteca potosina, México, por técnicas geomáticas. Revista de Geografía Norte Grande, 55, 141-156. doi: https://doi.org/10.4067/ s0718-34022013000200010

Andrade, G. de C., Da Silva, H. D., Ferreira, C. A., Bellote, A., \& Moro, L. (1995). Contribución del agua de lluvia en la oferta de nutrientes minerales para Eucalyptus grandis. Bosque, 16(1), 47-51.

Arguello, H. (1991). La descomposición de la materia orgánica y su relación con algunos factores climáticos y microclimaticos. Agronomía Colombiana, 8(2), 384-388.

Ávila, C. H., \& Zamora, P. (2010). Producción de hojarasca y materia orgánica en agroecosistemas cafetaleros marginales de Ocotal Chico, Veracruz, México," Polibotánica, 30, 69-87.

Bátori, Z., Erdős, L., Morschhauser, T., Török, P., \& Körmöczi, L. (2009). Vegetation of the Dolines in Mecsek Mountains (South Hungary) in relation to the Local Plant Communities. Acta Carsologica, 38(2-3), 237-252. doi: https://doi.org/10.3986/ ac.v38i2-3.125

Bátori, Z., Kormoczi, L., Erdos, L., Zalatnai, M., \& Csiky, J. (2012). Importance of karst sinkholes in preserving relict, mountain, and wet-woodland plant species under sub-Mediterranean climate: A case study from southern Hungary. Journal of Cave and Karst Studies, 74(1), 127-134. doi: https://doi.org/10.4311/2011lsc0216
Bátori, Z., Csiky, J., Farkas, T., Vojtkó, A., Erdős, L., Kovács, D., Wirth, T., Körmöczi, L. \& Vojtkó, A. (2014a). The conservation value of karst dolines for vascular plants in woodland habitats of Hungary: refugia and climate change. International Journal of Speleology, 43(1), 15-26. doi: https://doi.org/10.5038/1827-806x.43.1.2

Bátori, Z., Lengyel, A., Maróti, M., Körmöczi, L., Tölgyesi, C., Bíró, A., Tóth, M., Kincses, Z., Cseh, V., \& Erdős, L. (2014b). Microclimate-vegetation relationships in natural habitat islands: species preservation and conservation perspectives. Quarterly Journal of the Hungarian Meteorological Service, 118(3), 257-281.

Campo, J., García, F., Navarrete Segueda, A., \& Siebe, C. (2016). Almacenes y dinámicas del carbono orgánico en ecosistemas forestales tropicales de México. Terra Latinoamericana, 34(1), 31-38.

Çengel, Y. A. (2007). Transferencia de calor y masa. Un enfoque práctico. México: McGrawHill/Interamericana Editores, S.A. de C.V.

Cernatič-Gregorič, A., \& Zega, M. (2010). The Impact of Human Activities on Dolines (Sinkholes) - Typical Geomorphologic Features on Karst (Slovenia) and Possibilities of their Preservation. Geographica Pannonica, 14(1), 109-117.

Duque, G. (2003). Intemperismo o meteorización, Manual de Geología para Ingenieros. Retrieved from https://www.u-cursos.cl/usuario/ c19094b1ea89f1f08e243796b671e2e5/mi_blog/r/Manual_de_Geologia_Gonzalo_ Duque.compressed.pdf

Espinoza, L., Slaton, N. A., \& Mozaffari, M. (2012). Como interpretar los resultados de los análisis de suelos. Agricultura y Recursos Naturales, University of Arkansas System.

González-Medrano, F. (2012). Las zonas áridas y semiáridas de México y su vegetación. Ciudad de México: Instituto Nacional de Ecología, Secretaría de Medio Ambiente y Recursos Naturales.

Grageda-Cabrera, O. A., Vermoesen, A., van Cleemput, O., \& Peña-Cabriales, J. J. (2000). Efecto del tipo de suelo, humedad y fuente de nitrógeno en las emisiones de N2 y N2O. Terra, 18(1), 1-9.

Instituto Nacional de Geografía Estadística e Informática (INEGI), Carta estatal vegetación y uso actual, México, 2001a.

Instituto Nacional de Geografía Estadística e Informática (INEGI), Carta estatal de climas, México, 2001b.

Karmakar, R., Das, I., Dutta, D., \& Rakshit, A. (2016). Potential Effects of Climate Change on Soil Properties: A Review. Science International, 4(2), 51-73. doi: https://doi. org/10.17311/sciintl.2016.51.73

Koyoc-Ramírez, L. G., Mendoza-Vega, J., Pérez, J. C., \& Torrescano, N. (2015). Efectos de la perturbación antrópica en petenes de selva en Campeche, México. Acta Botánica Mexicana, 110, 89-103.

Li, F., Huang, J., Zeng, G., Liu, W., Huang, X., Huang, B., Gu, Y., Shi, L., He, X., \& He, Y. (2015). Toxic metals in topsoil under different land uses from Xiandao District, middle China: distribution, relationship with soil characteristics, and health risk assessment. Environmental Science and Pollution Research, 22(16), 12261-12275. doi: https://doi.org/10.1007/s11356-015-4425-7

Lobo, H. A. S. (2013). Circulação microclimática entre superfície, grandes dolinas e cavernas no carste de São Desidério, Bahia. Sociedade \& Natureza, 25(1), 163-178.

Morrone, J. J. (2005). Hacia una síntesis biogeográfica de México. Revista Mexicana de Biodiversidad, 76(2), 207-252.

NOM-021-RECNAT-2000. Establece las especificaciones de fertilidad, salinidad y clasificación de suelos. Estudios, muestreos y análisis. Diario Oficial de la Federación, México (2000).

Raschmanová, N., Miklisová, D., Kováč, Ĺ., \& Šustr, V. (2015). Community composition and cold tolerance of soil Collembola in a collapse karst doline with strong microclimate inversion. Biologia, 70(6), 802-811. doi: https://doi.org/10.1515/biolog-2015-0095

Rojas, C. (2015). Interpretación de la disponibilidad de fósforo en los suelos de Chile. Instituto de Investigaciones Agropecuarias, Serie Actas, 38.

Sainz, H., Echeverria, H., \& Angelini, H. (2011). Fósforo extractable en suelos agrícolas de 
las regiones Pampeana y extrapampeana de Argentina. Informaciones Agronómicas de Hispanoamérica, 4, 14-18.

Salazar, E. D. C., Zavala, J., Castillo, O., \& Cámara, R. (2004). Evaluación espacial y temporal de la vegetación de la Sierra Madrigal, Tabasco, México (1973-2003). Investigaciones Geográficas, 54. doi: https://doi.org/10.14350/rig.30128

Straulino, L. (2012). El intemperismo de calizas en monumentos prehispánicos mayas: El caso de la cornisa del edificio 5N2, Río Bec. Boletín de la Sociedad Geológica Mexicana. 64(1), 49-60.

Suarez, I. B., Gutiérrez, A., \& Bojorquez, A. R. (2010). Sótano de las golondrinas...Maravilla natural de México, acciones para su conservación como destino de turismo de naturaleza. Topofilia, 2(1), 1-17.

Suñer, L., \& Galantini, J. A. (2015). Texture influence on soil phosphorus content and distribution in semiarid Pampean grasslands. International Journal of Plant \& Soil Science, 7(2), 109-120. doi: https://doi.org/10.9734/ijpss/2015/16939

Vargas, G. (2002). La tropicalidad y el análisis geográfico. Reflexiones, 81(1).

Waltham, T., Bell, F.G., \& Culshaw, M. (2005). Sinkholes and subsidence: Karst and cavernous rocks in engineering and construction. Springer, Berlin, Heidelberg. doi: https://doi.org/10.1007/b138363

XLSTAT 2015. Software, Addinsoft (2015). 